\title{
Examining Moral Reasoning and Transactional Leadership behaviour in the Nigerian Public Sector
}

\author{
Chikelu Okey Felix, Abd Halim B Ahmad, Rosita Bint Arshad \\ Ghazali Shafie Graduate School of Government, Universiti Utara Malaysia, Kedah, Malaysia \\ okey.chikeluf@yahoo.com
}

\begin{abstract}
The relationship between moral reasoning and leadership style has received considerable attention for decades, however this has been not fully explicated as different leadership styles elist different ethical values. What constitutes moral behaviour is conflicting and subjective. This study examines public leaders' degree of moral judgment associated with leadership styles in a public sector organization. To test the hypothesized relationship, data were collected using questionnaire survey distributed to 550 workers out which 300 were found worthy to be used. The Defining Issues Test (DIT2) and the Multifactor leadership questionnaire (MLQ X5) were completed by leaders and subordinates respectively. The PLS path analysis of the structural model indicates significant statistical relationship between cognitive moral development (CMD) and transactional leadership style (TSL) $(\beta=-0.214, \mathrm{P}<0.012)$. However, we argue that cognitive moral development is amiable to the individual qualities of the leader that might necessitate the application of particular leadership style and behaviour. We also found collaboration evidence that leaders high in cognitive moral development are perceived more as transformational leaders by their subordinates. Finally, we suggest that the dichotomies between moral reasoning and leadership style are hinged more on individual leadership values and motivational beliefs.
\end{abstract}

Keywords: Moral reasoning, Transactional leadership, Public Sector

\section{Introduction}

This paper addresses the linkages between moral reasoning and transactional leadership style, suggesting that public leaders' degree of moral development arouses different motivational values and style of leadership (Burns, 1978). This relationship has attracted the attention of scholars and practitioners for ages. Today, viable and credible organizations have embraced the ethical reasoning and behaviour mantra for higher productivity. and effectiveness (Avolio \& Gardner, 2005). The role of leaders in motivating and inspiring subordinates is well documented (Avolio, Bass \& Jung, 1999). Leadership capacity in influencing or enhancing the ethical reasoning of subordinates is not in doubt, thus Leadership is mirrored through a person's morals and values, because the awareness of his beliefs and values motivates and acts as his moral conviction and reference point in decision making (Kouzes \& Posner, 2006). We examine the relationship between moral reasoning and transactional leadership style in order to give an insight or broaden the knowledge of its potentials as a factor that may have influence on the type of leadership style in use by an organization. the importance of ethical dilemmas in organizations and the world at large manifests in the growing body of literature on conflicts and dilemmas which impacts greatly on decision making.

Today, the perception is now more of a reality that the ethical decline in the public sector is on the rise with high consequences both for the sector and its leadership (Balogun, 1997). Kohlberg's cognitive, moral development theory remains the bedrock of most research on ethical reasoning applied to assess the stage of reasoning of managers (Fleming, Chow \& Su, 2010; Adams \& Dalfour, 2005). Individuals rationalize their decisions based on normative ethical theories (Dibie, 2007), and the dominant ones are ethical egoism, utilitarianism, deontology, the ethics of care, rights theory and justice theory (Derry \& Green, 1987). Aristotle (384-322) and Plato (380 BC) both gave an insight into features of justice for man and state, advocating for virtues and moral well being of others. The public sector, especially civil service as a concept connotes a permanent body of officials responsible for the execution of programs and policies of government (Balogun, 1997), who are staff of various ministries or departments under the executive arm of government (Beh, 2011). Ethics as a concept means standards of what is right or wrong motives and its consequences (Brown, 
Trevino \& Harrrison, 2005), a set of values and norms that relates to human conduct as appropriate or inappropriate (Sorkaa, 2003) and in the public service achieving a private gain to the detriment of the citizenry is a good example of unethical conduct (Chinua, 1983).

Ethics equally is a matter of value judgment on professional and occupational beliefs and morality (Barnett \& Brown, 1994), which are the normative values underpinning the public sector, these are ethical values that upholds the fabric of efficiency and service delivery within the sector (Barling \& Kevin, 2000). Therefore, effective and efficient management of resources and accountability is a global phenomenon, especially in a developing economy as Nigeria (Collier \& Vincent, 2014). Research has attributed the leadership crisis and failure in the Nigeria public sector to a lack of ethical practices and behaviour among the leaders (Achebe, 1983). Although most of the values usually linked to ethics in the public, are usually examined independent of the broader issue of leadership (Turner, Kaspesun, Matson, McCarthy, Correl, Christensen \& Schiller, 2003), and the major objective of this study is to empirically examine the influence of moral cognition development on transactional leadership behaviour in the Nigerian public sector. Thus, there is the need to further understand this relationship and how it impacts on style and ability of leaders to nurture public organizations of integrity that enhances trust of the subordinates and the entire citizenry through the application of ethical practices and moral leadership behaviour.

Transactional leadership Style: A variety of definitions exist in literature on leadership study, leadership is described as a group of people performing one activity or the other to achieve a common purpose (Yukl, 1999; Judge \& Piccolo, 2004). Over the years, many other definitions were added, the fact remains that leadership is a two-way approach that involves the leader and the subordinate (Jurkiewiez, 2005). Leadership has equally been described as the capacity to influence followers or subordinates towards a mission or vision (Hope \& Ronald, 2005), and this could happen within an organization formally or informally. However, for a leader to achieve formal influence on subordinates, he must be in a position of authority (Reiman, 1990), and informal influence takes place when an individual gets a responsibility. Transactional leadership is about performance based on what leaders and subordinates gives to each other (Bass, 1985). Proponents of transactional leadership and its ethicality argue that it spells out rules, while using reward and discipline (Kuhnert \& Lewis, 1987; Kanungo, 2001). Literature have evidenced that transformational leadership behavior is significantly positively related to follower's satisfaction (Yaun \& Lee, 2011), behavior (Bass, 1988), performing above the limit and general effectiveness (Turner et al., 2003). while the later or transactional leadership style is a performance based on outcomes and laissez-faire has been consistently correlated negatively with performance outcome associated with subordinates (Kirkbride, 2006; Yaun \& Lee, 2011). Transformational leaders could also become unethical when they pursue vested interest rather than collective interests (Yukl, 1998), on the other hand, transactional leadership has some components of transformational leadership, both represent different behavioral pattern of leadership (Fletcher \& Amold, 2011). The Transactional leadership style remains the prelude to other leadership styles as leadership is about exchange, expectation and reciprocity which connote what leaders and subordinates give to each other.

Cognitive Moral Development and Transactional leadership: There are three stages of Moral reasoning, the first being preconventional morality connoting unquestioned and uncritical compliance to authority and rules. The second being conventional or maintaining norms and role obligations while the third is the post conventional morality taking a more utilitarian approach and common good (Kohlberg, 1969). Ethics are more than rules and regulations about what could be regarded as morally correct action or wrong action based on motive of an action and its consequences. It connotes the sum totality or characteristic of a given profession. Ethics could be regarded as part of the larger society as it is not only concerned with individual behaviour and moral judgment, but with all the enabling institutions and policies of leadership processes. Ethical judgment is an acceptable solution to an ethical dilemma or between conflicting systems, values, beliefs which requires that a leader must make a decision to follow in achieving a set objective (Fraedrich \& Ferrell, 1992). It is important to note that each decision made by a leader is usually based on one criterion or the other, therefore ethical reasoning and ethical decisions sometimes are based on more than one ethical theory or ethical principle. For example, scholars are of the view that different ethical content will naturally invoke a different ethical reasoning approach as in cases of coercion and control; this normally will invoke the act utilitarianism ethical reasoning (Bass, 1985; Fletcher \& Amold, 2011). 
Kohlberg (1969) remains a reference point whenever moral judgment level is being considered, his theory of cognition (CMD), buttress the stages or processes of moral reasoning. People develop or move from the lowest to the highest stage, which is the post conventional stage, Moreover, ethical reasoning is based on individual capacity to develop to the highest level (Fritzsche \& Becker, 1984; Fradrick, Thoma \& Ferrell, 1994). While those, at the pre-conventional stage occupy themselves with what is right due largely to fear of punishment (stage1), or a sort of give and take (stage2), individuals at the conventional stage, do what is right based on expectation of others(stage3), By stage(4) individuals are principle minded and decides what is right due to their cherished values and standards irrespective of divergent views, at stage (5) individuals are concerned with justice, rights and faire play, while at stage (6) which is more of a theory than practicable as at now. However, Kohlberg's theory has been simplified into a manageable form (Rest, Narvaez, Bebeau, \& Thoma, 1999), while retaining the core elements of the former theory. Leaders with a higher moral reasoning are admired by subordinates (Cooper, 2004). Based on motivational values, leaders usually rationalize moral decisions on certain beliefs likely to influence the observer's desire to emulate such modelled individual behaviour (Dorfman, 1996; Eckhardt, 2002; Dunn, 2006).

Ethics and Public administration: A healthy or viable civil service in this study means as earlier conceptualized the capacity to honor obligations and discharge responsibilities or functions transparently in an ethical manner through the application of ethical decision making in work situations (Dunn, 2006). On the other hand, the public's expectations are twofold (Goodling, 2003), one that the government through its officials will manage and utilize public resources for general well being of the citizenry and secondly that the official's behaviour should be above board. Moral reasoning is pivotal or the heartbeat of legitimate government in achieving and delivering the dividends of democracy to the citizenry. It was argued that ethical conditions for civil servants have been with us for long and actually came with democracy. The importance of ethics in public administration cannot be overemphasized. Moral reasoning is a fundamental element in a democracy, even the secular and the religious attests to the essence of ethical leadership for effective and efficient administration (Reiman, 1990). Citizens are right to expect efficient and effective social services from the government in areas of health-care, education system and general security of life and property as this goes a long way to foster public trust (Cooper, 2004).

Research has evidenced that public trust and confidence increases when elected and appointed leaders make ethical decisions and exhibit ethical behaviors that promote the interest and well being of the entire citizenry. Public sector leaders are influential in the formulation and implementation of public policies and programs of the government as a result of the tremendous influence they exert, public leader's decisions and actions carry a lot of weight (Dugan \& Komives, 2007). However, if public officials are made up men and women of high morals, integrity, operating at a higher stage of ethical reasoning and behavioral character, the rate of ethical decline and loss of trust in the public sector will be drastically reduced or eradicated, as the public resources will henceforth be properly and judiciously managed for the benefit of the citizenry. Moreover, contingent reward is favorably disposed to ethical leadership (Kanungo, 2001), as it provides both leaders and subordinates morally sound base for mutual aspirations. In practice, both types of normative ethical theories are used, but people tend to have a propensity for one paradigm over another, what happens is rationalization and justification as one paradigm guides the philosophical purpose, psychology gives more insight into human cognition and behavioral patterns that ultimately affect ethical decision making, and prevents self-centeredness. Thus, it is posited that moral reasoning relates to transactional leadership style Hypothesis 11: There is a correlation between cognitive moral development and transactional leadership style.

\section{Methodology}

A quantitative approach was adopted to examine the influence of moral reasoning on transactional leadership style in the Nigerian public sector, using employees of the Kebbi State public service as the target population, while the population frame was obtained from the State's Civil Service Commission Kebbi that controls the various ministries in the state. Kebbi State is in the North- Western part of Nigeria and it was primarily selected for this study because her enviable size as one of the most populated within the geopolitical area in the country, having an estimated population of about 10 million people out of the total estimated Nigerian population of 140 million, therefore, Kebbi State represents a viable zone in Nigeria's 
public sector organization. The study adopted a stratified random sampling method due to the diversity of ministries mandate and the likely diversity equally in style of leadership and individual belief system. The essence is to gain more insight into the perception of employees on leadership styles. Four ministries were randomly selected from the ten ministries that were not affected by the recent mergers and equally are the core ministries with the largest population based on statistical report (2013). The total of employees of the four ministries is 14,337. Using the simplified Sampling table by Krejcie and Morgan (1970), a total sample size of 375 is deemed adequate for the study. However, the researcher decided to even it up to 300 , the reason is to enhance a large response rate due to poor research culture.

Instrument for data collection was the survey questionnaire to achieve the desired objectives. This is in respect to the nature of the formulated hypotheses in this study. For cognitive, moral development (CMD), the DIT-2 questionnaire, which is in two parts containing the instructions and stories of ethical, social problems, as well as questions on ethical issues raised was used. The transactional leadership style was measured using the MLQ X5 (Avolio, Zhu, Koh \& Bhatia, 2004). The instrument was divided into three sections, namely: Demographic factors, ethical reasoning, and the transactional leadership style. Respondents were required to answer questions on ethical reasoning/value orientation (CMD) using a 5 Likert-type scale adopted from a series of ethical dilemmas/value estimates and scenarios developed by eminent scholars (e.g., Schartz, Verkasalo, Antonovsky \& Sagio, 1997; Triandis \& Gelfand, 1998). The Partial Least Square - Structural Equation Modelling (PLS-SEM) software (Ringle, Sartedt \& Straub, 2002), was used for the analysis of the collected data in this study. In addition, Statistical Package for Social Sciences (SPSS) was used for the descriptive analyses of the respondents. In order to measure the significance of linear bivariate between the Cognitive Moral Development (CMD) and transactional leadership. A regression analysis was used to meet the objective of the research (Coakes, 2005). The choice of PLS-SEM in this study is based on the fact that PLS suits complexities of models, due largely to its flexibility in development and validation of models (Akter et al., 2011). Therefore, PLS was chosen to establish the construct, measurement and structural models of this study.

Measurement Model: The measurement model was evaluated by assessing the convergent validity, which is measured by loading, the average variance extracted (AVE) and the composite reliability (CR) result. The result revealed good items loading above the recommended threshold (0.5) by (Hair, Black, Babin, Anderson \& Tatham, 2006). Also, the result of the average variance extracted (AVE) indicates a value of 0.519 for transitional leadership style, but no value for Cognitive Moral Development (CMD), because it was measured by a single item (P-score value of the respondents). Concerning the composite reliability result which measures the internal consistency the measurement instrument, the analysis found a value of 0.811 for transactional leadership style. The values of the composite reliability are greater than the threshold value of 0.7 recommended by (Hair, Ringle \& Sarastedt, 2011), which indicated an internal consistency of the instrument. In addition, the finding revealed an R-square value of 0.447 indicating that $20 \%$ variance in transactional leadership style was explained by the cognitive moral reasoning (CMD). The summary of the measurement model in this study is presented in Table 1 below.

\section{Results}

Table 1: Summary of measurement model Result

\begin{tabular}{lccccc}
\hline \multicolumn{2}{l}{ Constructs Items } & Loading & AVE & CR & R-Square \\
\hline CMD & P-Score & 1.000 & Single term & Single term & \\
TSL & TSMBA4 & 0.690018 & 0.519 & 0.811 & 0.447 \\
& TSMBP2 & 0.814527 & & & \\
& TSMBP3 & 0.697929 & & & \\
& TSMBP4 & 0.671236 & & & \\
\hline
\end{tabular}

The analysis of the demographic profile of the respondents revealed that the largest proportion representing $72.7 \%$ of the respondents is from the ministry of education. The major percentage, $46.0 \%$ have between $1-5$ years working experience, $36.0 \%$ have between 6 - 10 years working experience, $16.3 \%$ has between 11 - 15 years of working experience, only $1.7 \%$ of the respondents have more than 16 years of service experience. On 
the hand, $67.0 \%$ of the respondents are male, while $33.0 \%$ are female. More so, the majority of the respondents are Muslims $66.7 \%, 25.3$ are Christians, while $8.0 \%$ are in the group of other religions. Concerning the age of the populations, $32.0 \%$ range between $30-39$ years, $36.7 \%$ are between $20-29$ years of age, $17.3 \%$ are between $40-49$ years of age, while $14.0 \%$ are more than 50 years of age. Furthermore, $29.3 \%$ of the respondents are officers in senior executive of their respective organizations, $43.0 \%$ made up the chief executive, while supervisors are 14.3 , and the remaining $13.3 \%$ are at a non-supervisory officer grade position. In the aspect of the respondents' educational qualification, $42.0 \%$ of the respondents have master degree, $18.0 \%$ have a bachelor degree, $37.3 \%$ are doctoral degree holders, while the remaining $2.1 \%$ have diploma qualifications. The result of the demographic analysis is presented in Table 2 of this study.

Table 2: Respondents demographic features

\begin{tabular}{|c|c|c|c|}
\hline Constructs & Items & Frequency & Percentage (\%) \\
\hline \multirow[t]{4}{*}{ Ministry } & Ministry of Education & 218 & 72.7 \\
\hline & $\begin{array}{l}\text { Ministry of works and } \\
\text { housing }\end{array}$ & 53 & 17.7 \\
\hline & Ministry of health & 15 & 5.0 \\
\hline & Ministry of finance & 14 & 4.7 \\
\hline \multirow[t]{4}{*}{ Work Experience } & $1-5$ years & 138 & 46.0 \\
\hline & $6-10$ years & 108 & 36.0 \\
\hline & $11-15$ years & 49 & 16.3 \\
\hline & 16 and above & 5 & 1.7 \\
\hline \multirow[t]{2}{*}{ Gender } & Male & 201 & 67.0 \\
\hline & Female & 99 & 33.0 \\
\hline \multirow[t]{3}{*}{ Religion } & Muslim & 200 & 66.7 \\
\hline & Christian & 76 & 25.3 \\
\hline & Others & 24 & 8.0 \\
\hline \multirow[t]{4}{*}{ Age Group } & $20-29$ years & 110 & 36.7 \\
\hline & 30-39 years & 96 & 32.0 \\
\hline & $40-49$ years & 52 & 17.3 \\
\hline & 50 and above & 42 & 14.0 \\
\hline \multirow[t]{4}{*}{ Position \& Responsibility } & Chief executive officer & 129 & 43.0 \\
\hline & Senior executive officer & 88 & 29.3 \\
\hline & Suppervisory grade & 43 & 14.3 \\
\hline & Non suppervisory grade & 40 & 13.3 \\
\hline \multirow[t]{4}{*}{ Highest Qualification } & Doctoral degree & 112 & 37.3 \\
\hline & Masters degree & 126 & 42.0 \\
\hline & Undergraduate degree & 54 & 18.0 \\
\hline & Diploma level & 8 & 2.7 \\
\hline
\end{tabular}

Descriptive Analysis of the Respondents Cognitive Moral Development: This study used Defining Issues Test (DIT-2) by (Rest, Narveaz, Thoma \& Bebeau, 1999), which focuses on the schema used by individual in solving ethical issues and which determine the respondent's stage of moral reasoning. The result shows that the major proportion, 151 of the respondents are at the preconventional stage of moral reasoning, 48 are in the conventional stages while those at the postcoventional stages of moral reasoning are 101. Table 3 presents the summary of the moral reasoning level of the respondents. 
Table: 3 Respondents Mean DIT P-Score by Moral Reasoning Stages/schemas ( $\mathbf{N}=300)$

\begin{tabular}{lllllll}
$\begin{array}{l}\text { Cognitive } \\
\text { Reasoning } \\
\text { Stages }\end{array}$ & Frequency & Percentages & Minimum & Maximum & Mean & $\begin{array}{l}\text { Std. } \\
\text { Deviation }\end{array}$ \\
\hline & & & & & & \\
Preconventional & 151 & 50.3 & 0.00 & 36.67 & 14.393 & 8.214 \\
Conventional & 48 & 16.0 & 30.00 & 40.00 & 35.069 & 3.369 \\
PostConventional & 101 & 33.7 & 43.33 & 73.33 & 53.171 & 5.743 \\
\hline
\end{tabular}

Discriminate validity determines the uniqueness of the concept under examination in the study's model (Hair et al., 2011) by comparing the square root of the average variance extracted, with the co relational values of each latent variable in the model. The result indicated that the AVE value of each construct is greater than its correlation with any other constructs in the model which shows that discriminant validity was achieved. Table 4 presents the results.

Table 4: Discriminant Validity Result

\begin{tabular}{lll}
\hline & CMD & TSL \\
\hline CMD & Single Item & \\
TSL & -0.057 & 0.730 \\
\hline
\end{tabular}

Structural Model: In testing the stated research hypotheses in this study, the structural model was assessed through the PLS path analysis. The result of the standard path coefficients $(\beta)$, standard error, P-value, and the decision taken on the hypotheses found that there is statistical significant relationship between cognitive moral development (CMD) and transactional leadership style (TSL) $(\beta=-0.214, P=<0.12)$ in the Nigerian public sector.

Source: survey.2015.

Table 4: Hypothesis Testing

\begin{tabular}{llllll}
\hline Path Coefficients & Beta & Std Error & T-Value & P-Value & Decision \\
\hline CMD -> TSL & -0.214 & 0.051 & $4.199^{* * *}$ & 0.012 & Supported \\
\hline
\end{tabular}

Discussion: This study gave an insight into cognitive moral development and transactional leadership styles and observed significant statistical relationships between them. Thus, it contributed to the ethical foundation of leadership dimensions with contingent reward being perceived as a moral procedure in leader and subordinate relationship. Most studies investigating transactional leadership, morality and ethics are usually done by assessing only behavioral items. Transformational leadership style on the other hand has always had a positive outcome on followers behaviour more that transactional leadership style, which is in line with other findings (e.g., Brown, Trevino \& Harrison, 2005; Judge \& Piccolo, 2004). Moreover, adopting the application of the (MLQ-5X), (Bass, \& Avolio, 2000), which is not an all encompassing of morality measure for both leadership styles tends to inhibit true pictures of research findings. Contingent reward is equally linked to transformational leadership in most empirical studies (Judge \& Piccolo, 2004), and provides core management ingredients for mutual benefits. However, theoretical arguments of moral base of transactional leadership are not supported by the results of the present research which rends credence to empirical evidence that higher moral development is related to better use of ethical leadership (Bass \& Steidlmeier, 1999).

\section{Conclusion}

Interestingly, the findings of this study corroborated and are consistent with some previous studies which indicated some statistical relationships between cognitive moral development and leadership style. Contingent reward is associated with both transactional and transformational leadership styles (Bass, 1985 and Bass \& Steiddlmeier, 1999), and this study has established and confirmed what was predicted to buttress the postulations, while earlier studies indicated a positive relationship at least with transformational 
leadership. Transactional leadership is both pragmatic and rational for leaders and subordinates thereby complementing transformational leadership that appeals to an individual's belief and emotions. It is indicated that contingent reward is equally ethical as it is morally based leadership style, whereby, terms are spelt out before a given task and negotiated properly by both parties. It connotes fairness, security to organizations and followers. However, there is the need to further explore the dichotomy puzzles between cognitive moral development and transactional leadership processes. This entails challenging some existing theories and the development of new research design.

\section{References}

Adams, G. B. \& Balfour, D. L. (2005). Public-service ethics and administrative evil: prospects and problems. Ethics in Public Management. Eds. H. George Frederickson and Richard K. Ghere, 114134.

Akter, K., Lanza, E. A., Martin, S. A., Myronyuk, N., Rua, M. \& Raffa, R. B. (2011). Diabetes mellitus and Alzheimer's disease: shared pathology and treatment?. British journal of clinical pharmacology, 71(3), 365-376.

Avolio, B. J. \& Gardner, W. L. (2005). Authentic leadership development: Getting to the root of positive forms of leadership. The leadership quarterly, 16(3), 315-338

Avolio, B. J., Bass, B. M. \& Jung, D. I. (1999). Re-examining the components of transformational and transactional leadership using the Multifactor Leadership. Journal of occupational and organizational psychology, 72(4), 441-462.

Avolio, B. J., Zhu, W., Koh, W. \& Bhatia, P. (2004). Transformational leadership and organizational commitment: Mediating role of psychological empowerment and moderating role of structural distance. Journal of organizational behavior, 25(8), 951-968.

Balogun, M. J. (1997). Enduring clientelism, governance reform and leadership capacity: A review of the democratization process in Nigeria. Journal of Contemporary African Studies, 15(2), 237-260.

Barling, J., Slater, F. \& Kevin Kelloway, E. (2000). Transformational leadership and emotional intelligence: An exploratory study. Leadership \& Organization Development Journal, 21(3), 157-161.

Barnett, T., Bass, K. \& Brown, G. (1994). Ethical ideology and ethical judgment regarding ethical issues in business. Journal of Business Ethics, 13(6), 469-480.

Bass, B. (1985). Leadership and performance beyond expectations New York: Free Pres

Bass, B. M. \& Avolio, B. J. (2000). Multifactor Leadership Questionnaire: MLQ; Sampler Set; Technical Report, Leader Form, Rater Form, and Scoring Key for MLQ Form 5x-short. Mind Garden.

Bass, B. M. \& Steidlmeier, P. (1999). Ethics, character, and authentic transformational leadership behavior. The leadership quarterly, 10(2), 181-217.

Bass, B. M. (1998). Transformational leadership: Industry, military, and educational impact. Hillsdale, NJ: Erlbaum.

Beh, L. (2011). Public ethics and corruption in Malaysia. Public administration in Southeast Asia: Thailand, Philippines, Malaysia, Hong Kong, and Macao, 171-191.

Brown, M. E., Treviño, L. K. \& Harrison, D. A. (2005). Ethical leadership: A social learning perspective for construct development and testing. Organizational behavior and human decision processes, 97(2), 117-134.

Burns, J. B. (1978). Leadership. New York: Harper \& Row.

Chinua, A. (1983). The Trouble with Nigeria. Enugu: Fourth Dimension Publishers.

Collier, P. \& Vicente, P. C. (2014). Votes and violence: evidence from a field experiment in Nigeria. The Economic Journal, 124(574), F327-F355.

Derry, R. \& Green, R. M. (1989). Ethical theory in business ethics: A critical assessment. Journal of Business Ethics, 8(7), 521-533.

Dibie, R. (2007). Ethical leadership, social responsibility and corruption in Nigeria. Journal of International Politics and Development, 5(1), 1-42.

Dugan, J. P. \& Komives, S. R. (2007). Developing leadership capacity in college students. College Park, Md.: National Clearinghouse for Leadership Programs Retrieved June, 21, 2012.

Dorfman, P. W. (1996). International and cross-cultural leadership research. Handbook for international management research, 267-349. 
Dunn, P. M. (2006). Aristotle (384-322 BC): philosopher and scientist of ancient Greece. Archives of Disease in Childhood-Fetal and Neonatal Edition, 91(1), F75-F77.

Eckhardt, G. (2002). Culture's consequences: Comparing values, behaviors, institutions and organizations across nations. Australian journal of management, 27(1), 89-94.

Fleming, D. M., Chow, C. W. \& Su, W. (2010). An exploratory study of Chinese accounting students' and auditors' audit-specific ethical reasoning. Journal of Business Ethics, 94(3), 353-369.

Fletcher, D. \& Arnold, R. (2011). A qualitative study of performance leadership and management in elite sport. Journal of applied sport psychology, 23(2), 223-242.

Fraedrich, J. \& Ferrell, O. C. (1992). Cognitive consistency of marketing managers in ethical situations. Journal of the Academy of Marketing Science, 20(3), 245-252.

Fraedrich, J., Thorne, D. M. \& Ferrell, O. C. (1994). Assessing the application of cognitive moral development theory to business ethics. Journal of Business Ethics, 13(10), 829-838

Fritzsche, D. J. \& Becker, H. (1984). Linking management behavior to ethical philosophy-An empirical investigation. Academy of Management Journal, 27(1), 166-175..

Goodling, N. A. (2003). Nigeria's Crisis of Corruption-Can the UN Global Program Hope to Resolve the Dilemma. Vand. J. Transnat'l L., 36, 997.

Hair, J. F., Black, W. C., Babin, B. J., Anderson, R. E. \& Tatham, R. L. (2006). Multivariate data analysis (Vol. 6). Upper Saddle River, NJ: Pearson Prentice Hall.

Hair, J. F., Ringle, C. M. \& Sarstedt, M. (2011). PLS-SEM: Indeed a silver bullet. Journal of Marketing Theory and Practice, 19(2), 139-152.

Cooper, T. L. (2004). Big questions in administrative ethics: A need for focused, collaborative effort. Public administration review, 64(4), 395-40

Hofstede, G. (1993). Cultural constraints in management theories. The Academy of Management Executive, 7(1), 81-94.

Hope, S. \& Ronald, K. (2005). Toward good governance and sustainable development: The African peer review mechanism. Governance, 18(2), 283-311.

Reiman, J. H. (1990). Justice and modern moral philosophy (p. 69). New Haven, Connecticut: Yale University Press.

Kohlberg, L. (1969). Stage and sequence: The cognitive-developmental approach to socialization. Rand McNally.

Judge, T. A. \& Piccolo, R. F. (2004). Transformational and transactional leadership: a meta-analytic test of their relative validity. Journal of applied psychology, 89(5), 755.

Jurkiewicz, C. L. (2005). Power and ethics: The communal language of effective leadership. Ethics in public management, 2, 95-113.

Kanungo, R. N. (2001). Ethical values of transactional and transformational leaders. Canadian Journal of Administrative Sciences/Revue Canadienne des Sciences de l'Administration, 18(4), 257-265.

Kirkbride, P. (2006). Developing transformational leaders: the full range leadership model in action. Industrial and commercial training, 38(1), 23-32.

Kuhnert, K. W. \& Lewis, P. (1987). Transactional and transformational leadership: A constructive/developmental analysis. Academy of Management review, 12(4), 648-657.

Kouzes, J. M. \& Posner, B. Z. (2006). The leadership challenge (Vol. 3). John Wiley \& sons.

Krejcie, R. V. \& Morgan, D. W. (1970). Determining sample size for research activities. Educational and Psychological Measurement, 30, 601-610.

Yuan, C. K. \& Lee, C. Y. (2011). Exploration of a construct model linking leadership types, organization culture, employees performance and leadership performance. Procedia-Social and Behavioral Sciences, 25, 123-136.

Rest, J. R., Narvaez, D., Thoma, S. J. \& Bebeau, M. J. (1999). DIT2: Devising and testing a revised instrument of moral judgment. Journal of Educational Psychology, 91(4), 644

Ringle, C. M., Sarstedt, M. \& Straub, D. (2012). A critical look at the use of PLS-SEM in MIS Quarterly. MIS Quarterly (MISQ), 36(1), iii-xiv.

Schwartz, S. H., Verkasalo, M., Antonovsky, A. \& Sagiv, L. (1997). Value priorities and social desirability: Much substance, some style. British Journal of Social Psychology, 36(1), 3-18.

Sorkaa, A. P. (2003). Development as Ethics and Accountability in Governance: The way forward for Nigeria (No. 1). Benue State University. 
Triandis, H. C. (1989). The self and social behavior in differing cultural contexts. Psychological review, 96(3), 506.

Triandis, H. C. \& Gelfand, M. J. (1998). Converging measurement of horizontal and vertical individualism and collectivism. Journal of personality and social psychology, 74(1), 118.

Turner, B. L., Kasperson, R. E., Matson, P. A., McCarthy, J. J., Corell, R. W., Christensen, L. \& Schiller, A. (2003). A framework for vulnerability analysis in sustainability science. Proceedings of the national academy of sciences, 100(14), 8074-8079.

Yukl, G. (1999). An evaluation of conceptual weaknesses in transformational and charismatic leadership theories. The leadership quarterly, 10(2), 285-305. 